\title{
ANALISIS EFISIENSI TRAFO FREKUENSI TINGGI PADA SUMBER TEGANGAN TINGGI COCKCROFT WALTON MBE LATEKS
}

\section{EFFICIENCY ANALYSIS OF HIGH-FREQUENCY TRANSFORMER IN COCKCROFT WALTON'S HIGH VOLTAGE SOURCE OF LATEX EBM}

\author{
Darsono, Suyamto, Taufik \\ Pusat Sains dan Teknologi Akselerator \\ JL. Babarsari Kotak Pos 6101 ykbb, Yogyakarta 55281 \\ e-mail: b_darsono@batan.go.id
}

Diterima 03 Juni 2014, diterima dalam bentuk perbaikan 16 Juli 2014, disetujui 22 Juli 2014

\begin{abstract}
ABSTRAK
ANALISIS EFISIENSI TRAFO FREKUENSI TINGGI PADA SUMBER TEGANGAN TINGGI COCKCROFT WALTON MBE LATEK. Trafo frekuensi tinggi (TFT) 1 fasa, $15 \mathrm{~kW}, 7 / 17,5 \mathrm{kV}, 40 \mathrm{kHz}$ yang dibuat telah dioperasikan pada MBE namun belum diketahui karakteristiknya. Efisiensi merupakan karakteristik TFT yang penting untuk dianalisis dalam rangka mengetahui kemampuannya dalam mencatu daya STT-MBE pada berbagai arus berkas elektron. Analisis dilakukan dengan menghitung rugi-rugi inti dan rugi-rugi lilitan dimana rugi inti tergantung pada bahannya, sedangkan rugi lilitan tergantung pada arus dan tahanannya dengan memperhatikan kenaikan suhu yang terjadi saat dioperasikan. Pada induksi magnet maksimum $B_{m} 0,15 \mathrm{~T}$ dan frekuensi operasi $40 \mathrm{kHz}$, diketahui rugi daya inti $611,78 \mathrm{~W}$ sedangkan rugi daya lilitan total 9,85 W pada beban penuh 1,07 A sehingga efisiensi trafo pada beban penuh 96,02\%. Efisiensi trafo dihitung dengan variasi arus beban atau arus berkas elektron I be dimana rugi daya lilitan berbanding kuadrat terhadap arus beban. Efisiensi maksimum ( $\eta_{\mathrm{m}}$ ) TFT di bawah beban penuh adalah sebesar 95,71\% terjadi pada l be $11 \mathrm{~mA}$ atau $92,4 \%$ beban penuh. Pada lbe yang lebih besar misalnya $12 \mathrm{~mA}$. TFT mengalami kondisi beban lebih sebesar $9,34 \%$. Jika dibandingkan dengan trafo tenaga yang mempunyai efisiensi maksimum sekitar $80 \%$ beban penuh, maka TFT yang dibuat mempunyai efisiensi maksimum pada persen beban yang lebih besar. Efisiensi TFT juga mempunyai kecenderungan sama dengan jenis trafo tenaga yaitu semakin besar bila bebannya semakin besar.
\end{abstract}

Kata Kunci : Mesin berkas elektron, trafo frekuensi tinggi, efisiensi, rugi inti, rugi lilitan,

\begin{abstract}
ABSTARCT
EFFICIENCY ANALYSIS OF HIGH-FREQUENCY TRANSFORMER IN COCKCROFT WALTON'S HIGH VOLTAGE SOURCE OF LATEX EBM. The high frequency transformer (HFT) of one phase, $15 \mathrm{~kW}, 7 / 17.5 \mathrm{kV}$, $40 \mathrm{kHz}$ made for latex EBM has been operated but its characteristics is still unknown. Efficiency is an important characteristic of the HFT to be analyzed in order to determine its ability to supply the power of high voltage source of EBM at various electron beam currents. The analysis was performed by calculating the core losses and winding losses where core loss depends on the material type while winding loss depends on its current and resistant. In this case the resistant value is determined by observing the temperature rise that occurs during operation. The core power loss $W$ at the maximum magnetic induction $B_{m}=0.15 T$ and the operating frequency of $40 \mathrm{kHz}$ is $611.78 \mathrm{~W}$ while the total coil power loss for full load of $1.07 \mathrm{~A}$ is $9.85 \mathrm{~W}$ so that the transformer efficiency at this load is $96.02 \%$. The efficiency of the transformer is calculated by varying the load current l be (electron beam current) where the coil power loss is proportional to the square of the load current. Maximum efficiency of the HFT under full load is $95.71 \%$ which is occurred at $l_{b e}$ of $11 \mathrm{~mA}$ or at $92.4 \%$ of full load. At larger $\mathrm{I}_{\text {be }}$,eg. $12 \mathrm{~mA}$, the HFT has been experiencing overload conditions by $9.34 \%$. When compared with the power transformer which has maximum efficiency of about $80 \%$ of full load, therefore the home made HFT has greater maximum efficiency in percent of load. The HFT efficiency also has the same tendency as this type of power transformer, where the greater the load the greater efficiency is.
\end{abstract}

Keywords: Electron beam machine, high frequency transformer, efficiency, core loss, cupper loss. 


\section{PENDAHULUAN}

$\mathrm{M}$ esin pemercepat elektron sering disebut Mesin Berkas Elektron (MBE) merupakan salah satu jenis peralatan sumber radiasi yang pada saat ini masih terus dikembangkan di Pusat Sains dan Teknologi Akselerator Batan (PSTA-Batan) Yogyakarta. Pengembangannya difokuskan pada peningkatan unjuk kerja peralatan tersebut sehingga dicapai kondisi yang optimal, baik tegangan tinggi maupun arus berkas elektronnya.

Sumber tegangan tinggi (STT) pemercepat merupakan bagian utama dan sangat penting dari MBE karena dengan tegangan tinggi tersebut elektron dapat dipercepat sehingga mempunyai energi yang sesuai dengan yang diinginkan. Banyak jenis STT yang salah satunya adalah jenis Cockcroft-Walton. STT berbasis Cockcroft-Walton (STT-CW) tediri dari dua bagian yaitu RF osilator daya tegangan tinggi dan pelipat tegangan (1). Pada RF osilator daya tegangan tinggi diperlukan trafo tegangan tinggi berfrekuensi tinggi (TFT). TFT yang digunakan pada STT-CW harus dioperasikan pada frekuensi tinggi agar pada saat diumpankan ke sistem pelipat tegangan akan memberikan keluaran dengan tegangan ripple dan drop yang rendah (2,3). TFT di samping digunakan pada STT-CW juga banyak digunakan untuk switching power supplies ${ }^{(4)}$, electrostatic precipitators(5), LCC resonant converter ${ }^{(6)}$. Standar rancangbangun trafo frekuensi tinggi sangat berbeda dengan standar trafo biasa. Beberapa hal yang harus diperhatikan pada TFT adalah: a) insulation material, b) core loss and heat dissipation, c) skin effect(4-6).

Pada tahun 2012 telah dirancangbangun sebuah TFT 1 fasa, $15 \mathrm{~kW}, 7 / 17,5 \mathrm{kV}, 40 \mathrm{kHz}$ karena TFT dengan spesifikasi seperti ini tidak ada di pasaran. Sampai saat ini TFT masih dipakai pada MBE lateks dan terus dilakukan pengujian dalam rangka mencapai spesifikasi tersebut di atas. Dari pengujian STT-CW, diketahui bahwa hasilnya belum optimum sesuai dengan yang diinginkan, oleh sebab itu perlu dilakukan analisis pada TFT yang telah dibuat untuk mengetahui kemampuannya berdasarkan pada data hasil uji yang ada(7,8). Efisiensi adalah salah satu karakteristik TFT yang penting untuk dianalisis dalam rangka mengetahui kemampuan TFT. Tujuan makalah ini adalah menganalisis efisiensi TFT untuk mengetahui kemampuan TFT dalam mentransfer daya dari sisi primer ke sekunder yang kemudian sebagai input ke pelipat tegangan dari STT. Diharapkan dari analisis ini dapat diketahui karakteristik efisiensi TFT sebagai fungsi beban arus berkas MBE dan bermanfaat pada pengujian STT-CW.

\section{Efisiensi Trafo}

Transformator (trafo) merupakan peralatan listrik yang berfungsi untuk memindahkan daya atau energi dari satu rangkaian ke rangkaian lain melalui gandengan magnet tanpa mengubah frekuensinya seperti ditunjukkan pada Gambar 1. Dalam hal ini sumber tegangan bolak-balik dari sisi primer energinya disimpan menjadi energi magnet di dalam inti, kemudian diubah lagi menjadi keluaran dalam bentuk tegangan bolak-balik di sisi sekunder.

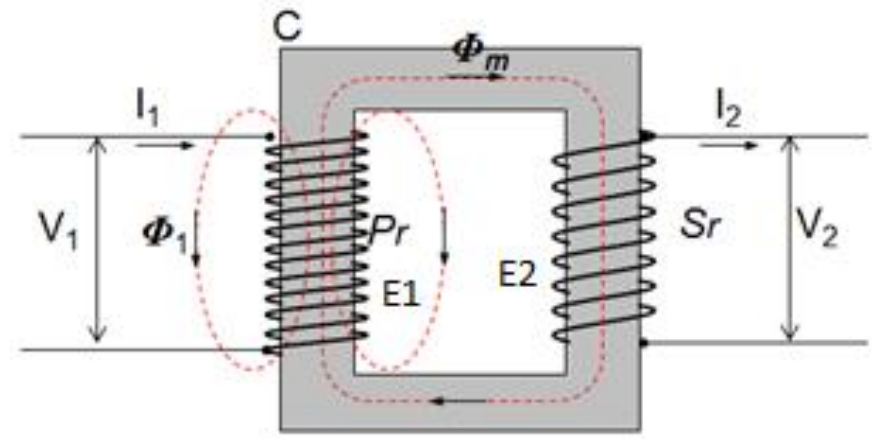

Gambar 1. Kumparan dan inti pada trafo.

Hubungan kelistrikan dan kemagnetan berupa pembangkitan gaya gerak listrik atau GGL $E$ di sisi primer maupun sekunder ditunjukkan pada persamaan (1).

$$
E=4,44 f N \phi_{m} \text { volt }
$$


dengan $\phi_{m}$ fluks maksimum pada inti (weber), $f$ frekuensi sumber $(\mathrm{Hz})$ dan $N$ adalah jumlah lilitan. Rangkaian ekivalen dari trafo pada Gambar 1 di atas ditunjukkan pada Gambar 2. Seperti diketahui bahwa setiap peralatan listrik pasti mempunyai rugi-rugi sehingga daya keluaran pasti akan lebih kecil dari pada daya masukannya, dan perbandingan antara daya keluaran terhadap daya masukan disebut efisiensi $(\eta)$.

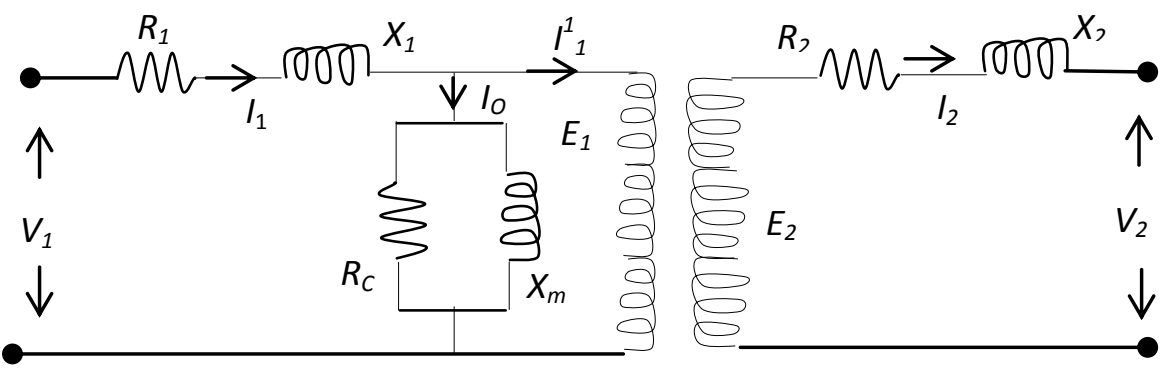

Gambar 2. Rangkaian ekivalen trafo.

$\begin{array}{clllll}\begin{array}{c}\text { dengan } \\ V_{1}\end{array} & & & & & \\ I_{1} & : & \text { Tegangan sumber ke sisi primer } & E_{1} & : & \text { GGL pada primer } \\ R_{1} & : & \text { Tahanan lilitan primer } & I_{1} & : & \text { Ekivalen arus sekunder pada primer } \\ X_{1} & : & \text { Reaktansi lilitan primer } & E_{2} & : & \text { GGL sekunder } \\ R_{C} & : & \text { Tahanan ekivalen inti besi } & R_{2} & : & \text { Tahanan lilitan sekunder } \\ X_{m}: & : & X_{2}: & : & \text { Reaktansi lilitan sekunder } \\ I_{0} & : & \text { Arus tansi ekivalen inti besi } & I_{2} & : & \text { Arus pada lilitan sekunder } \\ & & & V_{2} & : & \text { Tegangan sekunder (ujung beban) }\end{array}$

Rugi-rugi daya trafo seperti yang ditunjukkan pada Gambar 2, terdiri dari rugi lilitan primer, rugi inti dan rugi lilitan sekunder sehingga ${ }^{[9]}$,

$$
\begin{gathered}
\eta=\frac{P_{o}}{P_{i n}}=\frac{P_{o}}{P_{o}+\Sigma P_{r}} \times 100 \% \\
\eta=\frac{\text { keluaran }}{\text { keluaran+rugi.int } i+\text { rugi.lili } \tan \text { primer }+ \text { rugi.lili tan .sekunder }} \times 100 \% \\
\eta=\frac{V_{2} I_{2} \cos \varphi_{2}}{V_{2} I_{2} \cos \varphi_{2}+P_{c}+P_{C U 1}+P_{C U 2}} \times 100 \% \\
\eta=\frac{V_{2} I_{2} \cos \varphi_{2}}{V_{2} I_{2} \cos \varphi_{2}+P_{C}+I_{1}{ }^{2} R_{1}+I_{2}{ }^{2} R_{2}} \times 100 \%
\end{gathered}
$$

dengan $P_{0}$ daya keluar, $P_{\text {in }}$ daya masuk dan $\angle P_{\mathrm{r}}$ jumlah seluruh rugi daya, $P_{\mathrm{c}}$ rugi-rugi daya inti, $P_{\mathrm{cu}}$ rugi daya lilitan tembaga (watt) dan $\cos \varphi_{2}$ adalah faktor daya beban. Dari persamaan (2) besarnya $\eta$ dapat dihitung pada daya keluaran atau daya beban trafo tertentu bila rugi inti dan rugi-rugi lilitannya diketahui.

\section{Rugi Inti Trafo}

Rugi daya inti trafo sering disebut rugi tetap terdiri dari dari rugi histerisis $P_{\mathrm{h}}$ dan rugi arus pusar $P_{\mathrm{e}}$, dimana rugi histerisis disebabkan oleh fluks bolak balik pada inti besi sedangkan rugi arus pusar timbul karena adanya arus yang arahnya berputar di dalam bahan inti. Kedua jenis rugi-rugi tersebut tidak linear dan kompleks dan besarnya kebanyakan dinyatakan dalam persamaan empiris, tetapi semuanya terkait dengan konstata-konstanta dari inti $(K)$, frekuensi operasi $(f)$ dan rapat fluks atau induksi magnit maksimum di dalam inti $\left(B_{\mathrm{m}}\right)$ seperti yang ditunjukkan pada persamaan $(3)^{(3,10) \text {. }}$ 


$$
\begin{gathered}
P_{h}=K_{h} f B_{m}{ }^{1,6} \\
P_{e}=K_{e} K_{f}^{2} f^{2} B_{m}{ }^{2}=K_{e f} f^{2} B_{m}^{2} \\
P_{C}=P_{h}+P_{e}=a f^{c} B_{m}^{d}
\end{gathered}
$$

dengan $P_{\mathrm{h}}$ rugi histerisis, $P_{\mathrm{e}}$ rugi arus pusar, $K_{\mathrm{h}}, K_{\mathrm{e}}, K_{\mathrm{f}}, a, c$ dan $d$ konstanta-konstanta yang nilainya tergatung pada jenis bahan, bentuk dan susunan inti.

\section{Rugi Lilitan Trafo}

Rugi lilitan pada trafo terdiri rugi lilitan primer dan lilitan sekunder juga disebut rugi-rugi tembaga (Cu) karena lilitan dibuat dari bahan tembaga. Rugi-rugi tembaga terjadi disebabkan oleh pemanasan akibat arus yang mengalir, dan besarnya sebanding dengan kuadrat arus yang mengalir di dalam lilitan.

Seperti terlihat pada rangkaian ekivalen Gambar 2, antara lilitan primer dan sekunder terpisah oleh rangkaian inti sehingga analisis rangkaian tidak mudah. Maka dalam analisis untuk mencari besarnya rugi lilitan biasanya dilakukan dengan memindahkan rangkaian primer ke sisi sekunder atau sebaliknya sehingga rangkaian ekivalen trafo menjadi satu loop tertutup. Di samping itu mengingat besarnya arus tanpa beban $I_{0}$ kecil maka biasanya diabaikan terhadap arus beban penuh, sehingga rangkaian ekivalen trafo dapat digambarkan secara pendekatan seperti yang ditunjukkan pada Gambar $3^{(9)}$.

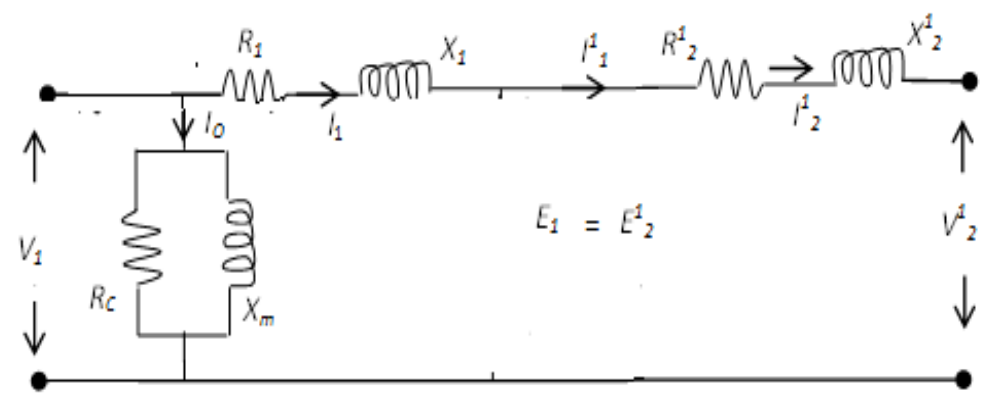

Gambar 3. Rangkaian ekivalen trafo, lilitan sekunder dipindahkan ke sisi primer dan arus tanpa beban diabaikan terhadap arus beban penuh.

Dari Gambar 3 terlihat bahwa $I_{1}=I_{1}{ }_{1}=I^{1}{ }_{2}$ dimana $I_{1}{ }_{1}$ dan $I_{2}{ }_{2}$ adalah arus di lilitan sekunder yang dirasakan oleh sisi primer. Untuk menghitung rugi daya lilitan tembaga primer dan sekunder pada umumnya rangkaian lilitan primer dipindahkan ke sisi sekunder kemudian trafo dibebani, sehingga rangkaian ekivalen pada sisi beban seperti yang ditunjukkan pada Gambar 4.

Besarnya tahanan lilitan primer $R_{1}$ pada saat dipindahkan ke sisi sekunder menjadi $R_{1} / a^{2}$, dengan a adalah perbandingan transformasi, sehingga tahanan lilitan total primer dan sekunder dilihat dari sisi sekunder adalah $\left(R_{1} / a^{2}+R_{2}\right)$. Dengan melihat Gambar 4 maka efisiensi trafo pada persamaan (2) dapat dituliskan menjadi persamaan (4) berikut.

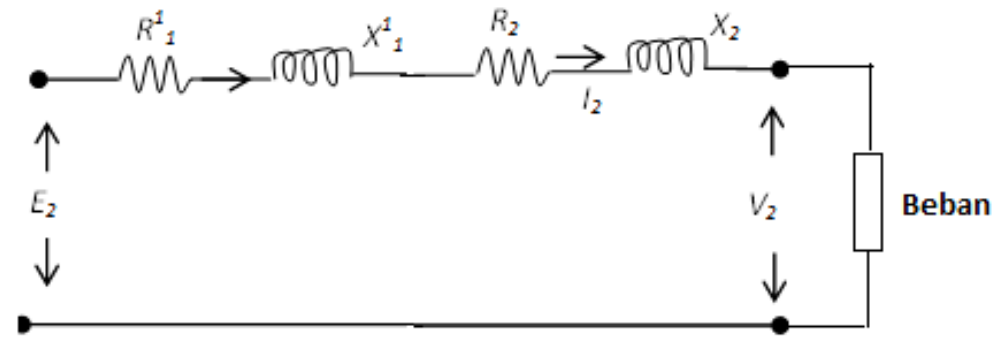

Gambar 4. Rangkaian ekivalen trafo berbeban dilihat di sisi sekunder. 


$$
\eta=\frac{V_{2} I_{2} \cos \varphi_{2}}{V_{2} I_{2} \cos \varphi_{2}+P_{C}+I_{2}{ }^{2}\left(R_{1} / a^{2}+R_{2}\right)} \times 100 \%
$$

Dari persamaan 4, efisiensi trafo dapat dihitung untuk setiap besar pembebanan atau setiap daya keluar trafo apabila besarnya rugi daya inti $P_{c}$ yang bersifat tetap dan tidak tergantung beban serta tahanan lilitan primer dan sekunder diketahui. Pada kenyataannya $R_{1}$ dan $R_{2}$ yang dibuat dari bahan tembaga nilainya berubah terhadap suhu. Untuk menghitung perubahannya digunakan persamaan (5) yang diturunkan dari grafik efek suhu terhadap tahanan bahan tembaga pada Gambar $5^{(11)}$.

$$
\frac{234,5+t_{1}}{R_{1}}=\frac{234,5+t_{2}}{R_{2}}
$$

dengan $R_{1}$ tahanan pada suhu $t_{1}, R_{2}$ tahanan pada suhu $t_{2}$, dan 234,5 disebut suhu mutlak yang disimpulkan dari bahan (inferred absolute temperatur of material).

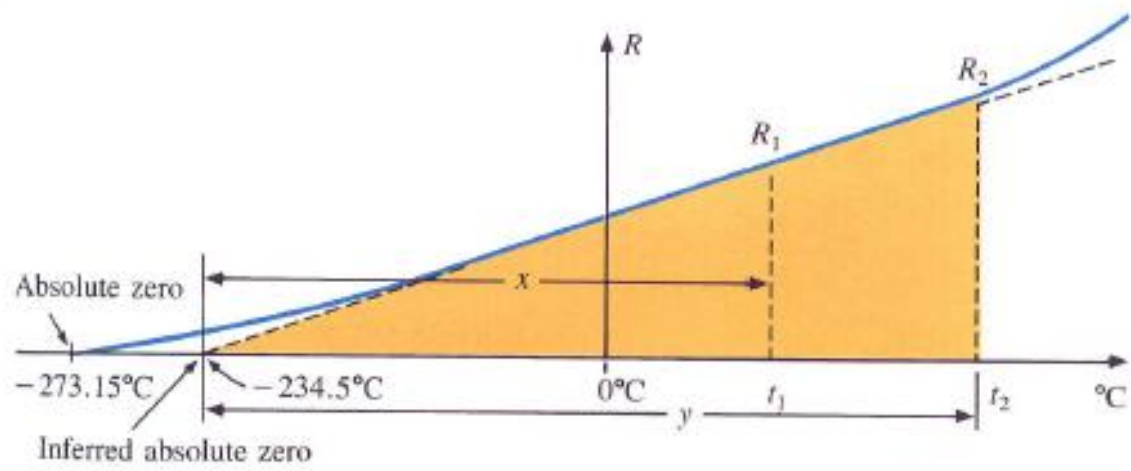

Gambar 5. Efek suhu terhadap tahanan bahan tembaga.

Di samping itu perubahan nilai tahanan juga dapat dihitung dengan persamaan (6) yaitu dengan memanfaatkan besarnya koefisien suhu bahan tembaga pada suhu $20{ }^{\circ} \mathrm{C}$ yang besarnya 0,00393 .

$$
R_{t}=R_{20}\left\{1+\alpha_{20}\left(t-20^{\circ} C\right)\right\}
$$

\section{METODOLOGI}

\section{Efisiensi Trafo}

Untuk menentukan besarnya efisiensi trafo hal yang paling penting adalah menghitung besarnya rugi-rugi daya yaitu rugi daya inti baik rugi histerisis maupun rugi arus pusar dan rugi daya lilitan tembaga primer maupun sekunder. Dari hasil perhitungan kedua jenis rugi-rugi trafo ini kemudian efisiensi TFT dihitung menggunakan persamaan (4).

\section{Rugi Inti Trafo}

Untuk mengetahui rugi-rugi inti dapat dilakukan melalui pengujian tanpa beban (no load test) atau pengujian hubung buka (open circuit test) dan dengan perhitungan. Pada pengujian tanpa beban, disyaratkan sisi primer harus dicatu dengan tegangan dan frekuensi rating-nya dan hal ini tidak dilakukan karena kesulitan dalam penyediaan catu daya TFT yaitu $7 \mathrm{kV}, 40 \mathrm{kHz}$. Oleh sebab itu untuk menentukan besarnya rugi-rugi TFT dilakukan melalui perhitungan. Seperti diketahui bahwa rugi inti $P_{c}$ terdiri dari rugi histerisis dan rugi arus putar (eddy current) disebut sebagai rugi tetap karena nilainya tetap bila dioperasikan pada frekuensi tetap misalnya $50 \mathrm{~Hz}$ seperti pada trafo distribusi PLN. Pada kenyataannya nilai rugi inti berubah tergantung pada frekuensi operasi oleh sebab itu perhitungan besarnya rugi inti harus mempertimbangkan frekuensi operasi dari trafo seperti yang ditunjukkan pada persamaan (3). Perhitungan masing-masing rugi histerisis dan rugi arus pusar sulit dilakukan berhubung konstanta-konstata $K_{\mathrm{h}}, K_{\mathrm{e}}$ dan $K_{\mathrm{f}}$ sulit ditentukan. Oleh karena itu perhitungan rugi inti dilakukan menggunakan 
persamaan (3) dengan $P_{\mathrm{C}}(\mathrm{mW})$, frekuensi $f(\mathrm{kHz})$ dan induksi magnet $B_{\mathrm{m}}$ (kgauss), sedangkan nilai konstanta-konstanta $a, c$ dan $d$ tergantung pada jenis bahan dan bentuk inti ditentukan pada saat dilakukan rancangbangun $(3,10)$.

\section{Rugi Lilitan Trafo}

Seperti halnya penentuan rugi inti, rugi-rugi daya lilitan juga dapat dilakukan dengan dua cara yaitu melalui pengujian hubung singkat (short circuit test) dan dengan perhitungan. Pada pengujian hubung singkat sisi sekunder dihubung singkat, tegangan catu daya primer dinaikkan dan arus hubung singkat $\left(I_{2 s c}\right)$ diukur sampai mencapai atau sama dengan arus beban penuh trafo. Seperti pada pengujian hubung buka, dengan alasan yang sama pengujian hubung singkat juga sulit dilakukan, di samping bahwa arus beban penuh yang berasal dari arus berkas pada MBE juga tidak diketahui. Oleh sebab itu penentuan besarnya rugi-rugi lilitan juga dilakukan melalui perhitungan, dimana rugi lilitan tembaga primer adalah $l_{1}{ }^{2} R_{1}$ dan rugi lilitan tembaga sekunder $I_{2}{ }^{2} R_{2}$. ditentukan berdasarkan perhitungan sebagai berikut.

1. Arus $I_{1}$ dan $I_{2}$ seharusnya ditentukan berdasarkan pengukuran besarnya arus berkas elektron pada saat MBE dioperasikan, namum dalam hal ini ditentukan pada saat beban penuh dari TFT.

2. Tahanan $R_{1}$ dan sekunder $R_{2}$ ditentukan berdasarkan pengukuran pada suhu lingkungan $20{ }^{\circ} \mathrm{C}$ saat dilakukan rancangbangun TFT.

3. Perubahan nilai $R_{1}$ dan $R_{2}$ yang diakibatkan oleh kenaikan suhu pendingin dihitung berdasarkan disipasi panas rugi-rugi daya yang timbul pada saat trafo dibebani menggunakan persamaan (5) dan (6).

\section{HASIL DAN PEMBAHASAN}

\section{Rugi Inti Trafo, $P_{C}$}

Seperti telah dijelaskan bahwa TFT di-desain pada $15 \mathrm{~kW} ; 7 / 17,5 \mathrm{kV} ; 40 \mathrm{kHz}$ maka dengan mempertimbangkan faktor desain induksi medan magnet maksimum $B_{m}$ ditentukan sebesar 0,15T. Dari perhitungan desain diperoleh kebutuhan inti sebanyak tiga pasang dengan volume tiap pasang $1792 \mathrm{~cm}^{3}$. Dengan menggunakan persamaan (3), untuk bahan inti ferit MnZn jenis F pada frekuensi $10 \mathrm{kHz}<f<100 \mathrm{kHz}$ besarnya koefisien $a=0,06798, c=1,72$ dan $d=2,66$ diperoleh $P_{C}=0,1138 \mathrm{~W} / \mathrm{cm}^{3}$. Untuk melihat lebih detail pengaruh medan frekuensi terhadap disipasi daya magnet dapat dilihat pada acuan (3). Rugi inti total adalah $P_{C}=3 \times 1792$ $\mathrm{cm}^{3} \times 0,1138 \mathrm{~W} / \mathrm{cm}^{3}=611,78 \mathrm{~W}^{(3,10)}$. Dari lampiran 1 terlihat bahwa $B_{\mathrm{m}}$ diambil pada nilai yang terkecil dengan pertimbagan agar arus magnetisasi yang diperlukan tidak terlalu besar sehingga rugi daya intinya kecil.

\section{Rugi Lilitan Trafo, $P_{\mathrm{cu}}$}

Rugi-rugi lilitan primer dan sekunder ditentukan melalui perhitungan, dimana besar arus ditentukan berdasarkan pada besar beban sedangkan besar tahanan lilitan didasarkan pada hasil pengukuran. Pada perhitungan rugi lilitan ini ditentukan bahwa trafo dibebani secara penuh sesuai dengan desain yaitu $15 \mathrm{~kW} ; 17,5$ $\mathrm{kV}$. Dengan mengambil besarnya faktor daya beban yang pada umumnya sebesar 0,8 tertinggal, maka dapat dihitung besar arus sekunder trafo atau arus beban penuh yaitu,

$$
I_{2}=I_{f l}=\frac{P_{o}}{V_{2} \cos \varphi_{2}}=\frac{15 \times 10^{3}}{\left(17,5 \times 10^{3}\right) \times 0,8}=1,07 \mathrm{~A}
$$

Besarnya tahanan lilitan primer dan sekunder diambil dari hasil pengukuran pada suhu $20{ }^{\circ} \mathrm{C}$ pada saat dilakukan desain, dimana lilitan berupa bundle dari kawat tembaga (email) diameter $0,3 \mathrm{~mm}$, tiap bundle terdiri dari 32 kawat untuk primer dan 20 buah untuk sekunder. Jumlah lilitan primer 56 buah panjang $32 \mathrm{~m}$ sedangkan untuk lilitan sekunder jumlah lilitan 220 buah dan panjang $137 \mathrm{~m}^{(7)}$. Dari pengukuran menggunakan LCR meter pada suhu lingkungan $20^{\circ} \mathrm{C}$, diketahui bahwa tahanan rata-rata lilitan primer dan sekunder masing-masing adalah 0,071 $\Omega$ dan $0,032 \Omega$ untuk setiap panjang $2,5 \mathrm{~m}$.

Jadi besar tahanan lilitan primer adalah $32 / 2,5 \times 0,071=0,91 \Omega$ dan tahanan lilitan sekunder $137 / 2,5 \times$ $0,032=1,75 \Omega$. Bila lilitan primer dipindahkan ke sisi sekunder nilainya menjadi $R_{1} / a^{2}$, dengan a perbandingan lilitan yang besarnya sama dengan $7 / 17,5=0,4$ sehingga $R_{1} / a^{2}=0,91 /(0,4)^{2}=5,68 \Omega$. Jadi tahanan ekivalen total TFT adalah $R_{\mathrm{e}}=\left(R_{1} / \mathrm{a}^{2}+R_{2}\right)=5,68+1,75=7,43 \Omega$. 
Besar tahanan lilitan tembaga $R_{1}$ dan $R_{2}$ dipengaruhi oleh suhu lilitan, sehingga besar tahanan kedua lilitan tersebut harus dihitung pada suhu minyak pendingin pada saat trafo dioperasikan dalam keadaan tunak (steady state), dimana suhu lilitan dianggap sama dengan suhu minyak pendingin. Besar kenaikan suhu pendingin dihitung berdasarkan asumsi awal disipasi panas sebesar $650 \mathrm{~W}$ dan suhu sekitar $30{ }^{\circ} \mathrm{C}$, kemudian dengan menggunakan persamaan konduksi pada dinding casing dan persamaan konveksi baik pada minyak pendingin maupun udara luar diperoleh suhu minyak pendingin $60,87^{\circ} \mathrm{C}(12)$. Dengan demikian besar tahanan lilitan total pada suhu tersebut adalah $R_{\mathrm{t}}=7,43\{1+0,00393(60,87-20)\}=7,43 \times 1,16=8,61 \Omega$, dan rugi daya lilitan pada saat beban penuh $P_{\text {cuadalah }} I_{2}^{2}\left(R_{1} / a^{2}+R_{2}\right)=1,072 \times 8,61=9,85 \mathrm{~W}$ serta rugi daya total $\left(\sum P_{\mathrm{r}}\right)$ TFT adalah $611,78+9,85$ $=621,63 \mathrm{~W}$.

\section{Efisiensi Trafo $\eta$}

Dengan menggunakan persamaan (4) maka efisiensi trafo pada saat beban penuh adalah

$$
\eta=\frac{15 \times 10^{3}}{15 \times 10^{3}+621,63} \times 100 \%=\frac{15000}{15621,63} \times 100 \%=96,02 \%
$$

Bila dihitung kembali bahwa saat trafo dioperasikan pada beban penuh mempunyai rugi-rugi daya sebesar $621,63 \mathrm{~W}$ yang semua terdisipasi menjadi panas kemudian kenaikan suhu minyak pendingin linier terhadap rugi-rugi daya, maka suhu minyak pendingin pada saat beban penuh sebenarnya adalah $(621,63 / 650) \times 60,78{ }^{\circ} \mathrm{C}=$ $58,12{ }^{\circ} \mathrm{C}$. Pada suhu tersebut besar tahanan lilitan adalah $8,54 \Omega$ sehingga mempunyai perbedaan tahanan yang sangat kecil sebesar 8,61- 8,54 $=0,07 \Omega$, sehingga dapat diabaikan.

Pada umumnya suatu trafo jarang dioperasikan pada beban penuh atau dibebani di bawah beban penuh, misalnya $1 / 2$ (setengah) atau 1/4 (seper empat) beban atau pada beban yang lain. Kenyataan yang terjadi di lapangan adalah bahwa beban TFT yang telah dibuat hanya kecil sebab untuk menghasilkan arus berkas yang cukup besar pada MBE lateks tidak mudah dicapai karena tergantung dari banyak faktor.

Dari pengukuran-pengukuran yang telah dilakukan dalam pengujian MBE diketahui bahwa pada tegangan keluaran STT $200 \mathrm{kV}$ belum terjadi discharge dan arus keluarnya $\left(I_{\mathrm{STT}}\right)$ yang terdiri dari arus bocor $\left(I_{\mathrm{L}}\right)$, arus kolom $\left(I_{C}\right)$ dan arus berkas elektron $\left(l_{\text {be }}\right)$ berkisar 4,5 kali dari $l_{b e}{ }^{(8)}$. Bila tegangan riak (ripple) dan drop pada sistem pelipat tegangan diabaikan karena kapasitansi dan frekuensinya besar, maka tegangan masuk (keluar dari TFT) ke rangkaian pelipat yang mempunyai jumlah tingkat $n=10$ adalah $1 / 20$ tegangan output $\mathrm{CW}$. Karena pada daya yang tetap besarnya arus berbanding terbalik dengan tegangan maka besar arus masuk ke rangkaian pelipat tegangan

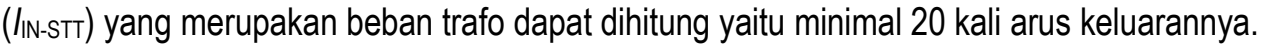

Dengan mengingat bahwa rugi daya lilitan berbanding kuadrat terhadap arus beban yang dalam hal ini adalah $\iota_{\mathbb{N}-S T T}$, maka efisiensi $(\eta)$ trafo dengan variasi beban dapat dihitung dengan cara seperti di atas. Hasilnya ditunjukkan pada Tabel 1 dengan asumsi bahwa perubahan tahanan lilitan yang diakibatkan oleh kenaikan suhu karena kenaikan beban diabaikan sebab nilainya sangat kecil.

Sebagai ilustrasi perhitungan diambil data eksperimen dari Logbook MBE, misalnya $I_{\mathrm{be}}=2 \mathrm{~mA}, I_{\mathrm{sTT}}=9 \mathrm{~mA}$, $I_{\mathrm{N}-\mathrm{STT}}=9 \times 20=180 \mathrm{~mA}$ atau $(180 / 1070) \times 100 \%=16,82 \%$ dari beban penuh. Maka efisiensi trafo adalah

$$
\eta=\frac{(0,168) 15 \times 10^{3}}{(0,168) \times 15 \times 10^{3}+611,78+(0,1682)^{2} \times 9,85} \times 100 \%=\frac{2520}{3132,05} \times 100 \%=80,445 \%
$$

Dari Tabel 1 terlihat bahwa efisiensi maksimum TFT yang mungkin dapat dicapai adalah sangat besar karena rugi-rugi daya lilitan sangat kecil. Hal seperti ini juga akan terjadi pada kelompok dan jenis trafo non tenaga seperti trafo hemat, trafo pengaturan, trafo frekuensi, trafo pengukuran dan trafo untuk test atau pengujian. Pada umumnya untuk trafo tenaga misalnya trafo distribusi atau trafo transmisi yang biasa dipakai untuk melayani beban pada industri dan rumah tangga, karakteristik efisiensinya seperti yang ditunjukkan pada Gambar 6, dimana efisiensi maksimum yang dapat dicapai hanya sekitar $80 \%\left({ }^{(13)}\right.$. Hal ini terjadi karena inti trafo tenaga dibuat dari bahan besi lunak dengan permeabilitas $(\mu)$ kecil sehinga rugi intinya besar. Berbeda dengan TFT yang dibuat, dimana intinya dibuat dari bahan ferit yang mempunyai $\mu$ sangat besar dan rugi-rugi intinya baik rugi histerisis maupun rugi arus pusarnya berharga kecil sehingga efisiensinya akan besar. 
Dari Tabel 1 juga dapat diketahui bahwa efisiensi trafo semakin besar bila bebannya semakin besar. Pada Gambar 7 ditunjukkan pada faktor daya beban $\cos \varphi=0,2$ trafo tenaga mempunyai efisiensi maksimum $65 \%$ dan pada faktor daya beban $\cos \varphi=1,0$ efisiensinya dapat mencapai $90 \%$. Pada TFT yang dibuat, karakteristik efisiensinya pada faktor daya beban $\cos \varphi=0,8$ mirip dengan trafo tenaga seperti ditunjukkan pada Gambar 8 .

Tabel 1. Efisiensi $(\eta)$ TFT pada berbagai variasi beban.

\begin{tabular}{ccccc}
\hline $\begin{array}{c}\text { Arus berkas } \\
\text { elektron, } \\
I_{\text {be }}(\mathrm{mA})\end{array}$ & $\begin{array}{c}\text { Arus keluar dari sistem } \\
\text { pelipat tegangan, } \\
I_{\text {STT }}(\mathrm{mA})\end{array}$ & $\begin{array}{c}\text { Arus masuk ke sistem } \\
\text { pelipat tegangan, } \\
\text { lin-STT }_{(\mathrm{mA})}\end{array}$ & $\begin{array}{c}\text { Beban trafo } \\
(\%)\end{array}$ & $\begin{array}{c}\text { Efisiensi TFT, } \\
\eta(\%)\end{array}$ \\
\hline 1 & 4,5 & 90 & 8,4 & 67,31 \\
\hline $\mathbf{2}$ & $\mathbf{9 . 0}$ & 180 & 16,8 & $\mathbf{8 0 , 4 5}$ \\
\hline 3 & 13,5 & 270 & 25,2 & 86,05 \\
\hline 4 & 18.0 & 360 & 33,6 & 89,15 \\
\hline 5 & 22,5 & 450 & 42 & 91,12 \\
\hline 6 & 27.0 & 540 & 50,4 & 92,48 \\
\hline 7 & 31,5 & 630 & 58,8 & 93,48 \\
\hline 8 & 36.0 & 720 & 67,2 & 94,23 \\
\hline 9 & 40,5 & 810 & 75,6 & 94,83 \\
\hline 10 & 45.0 & 900 & 84 & 95,32 \\
\hline 11 & 49,5 & 990 & 92,4 & 95,71 \\
\hline 12 & 54.0 & 1.080 & 100,8 & 96,05 \\
\hline
\end{tabular}

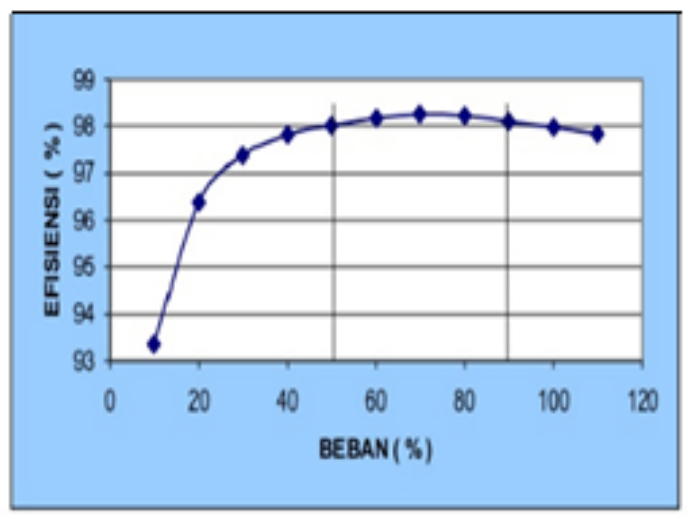

Gambar 6. Efisiensi trafo tenaga secara umum.

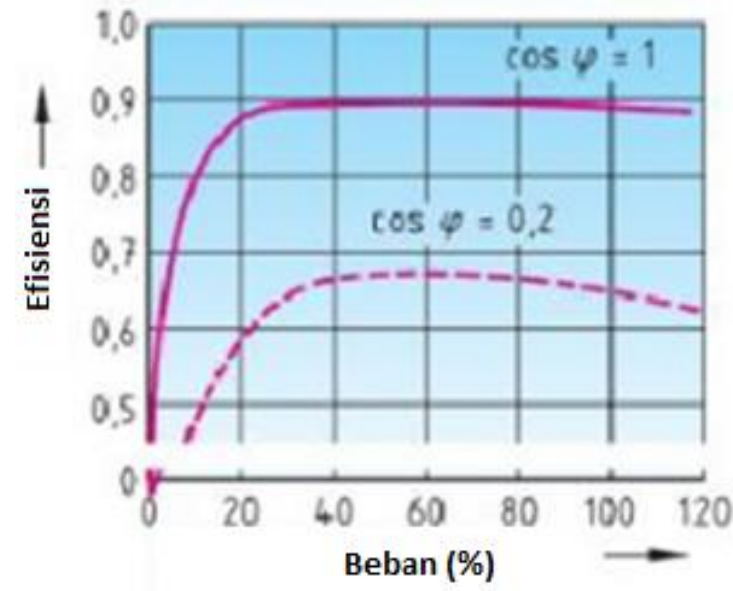

Gambar 7. Efisiensi trafo tenaga pada $\cos \varphi=0,2$ dan $\cos \varphi=1$. 


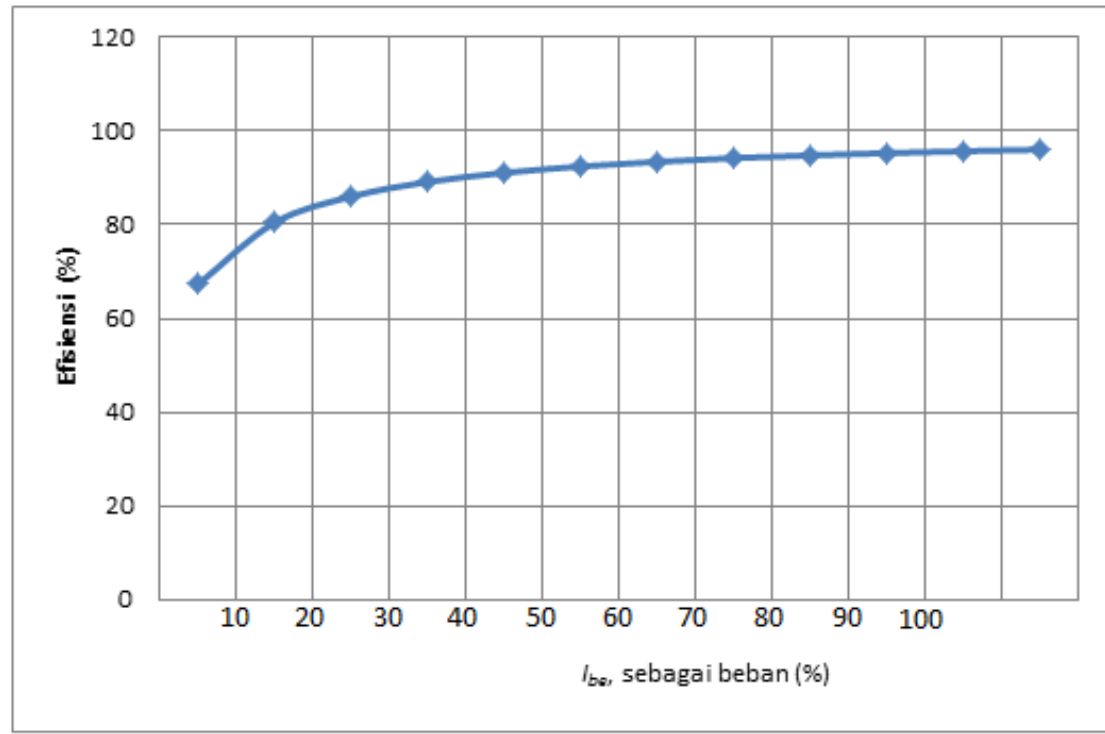

Gambar 8. Pengaruh beban terhadap efisiensi TFT.

Dari Gambar 9 terlihat bahwa bila MBE dioperasikan pada $I_{\text {be }} 11 \mathrm{~mA}$ atau pada 92,4 \% beban penuh, efisiensi maksimum TFT yang dibuat sebesar $95,71 \%$. Pada $I_{\text {be }}$ dan $I_{\text {st }}$ yang lebih besar, misalnya $I_{\text {be }} 12 \mathrm{~mA}$ atau ISTT $54 \mathrm{~mA}$, TFT mengalami kondisi beban lebih atau overload sebesar $9,34 \%$.

\section{KESIMPULAN}

TFT yang telah dibuat mempunyai efisiensi yang lebih besar dibanding trafo tenaga karena inti trafo dibuat dari bahan ferit sehingga rugi intinya kecil, di samping itu rugi-rugi lilitan primer dan sekunder juga kecil karena beban dan tahanannya kecil. Efisiensi TFT akan semakin besar bila bebannya semakin besar dan efisiensi maksimum akan terjadi pada arus berkas elektron $I_{\text {be }}$ di atas $11 \mathrm{~mA}$ atau $I_{\mathrm{sTT}} 49,5 \mathrm{~mA}$ yaitu sebesar $95,71 \%$. Pada $I_{\text {be }}$ dan $I_{\text {STT }}$ yang lebih besar, TFT mengalami beban lebih atau over load sebesar 9,34 \% dari arus beban penuh. Karakteristik efisiensi TFT yang dibuat sebagai fungsi persen beban mirip dengan trafo tenaga hanya nilainya lebih besar.

\section{DAFTARA PUSTAKA}

1. DARSONO, "Rancangan Dasar Mesin Berkas Elektron 300 keV/20 mA Untuk Industri Lateks Alam", Prosiding PPI Teknologi Akselerator dan Aplikasinya, Edisi khusus, Yogyakarta, (2006) 47-61

2. SUYAMTO dkk, Rancangbangun Transformator Frekuensi Tinggi untuk Sumber Tegangan Tinggi Cockcroft Walton-MBE, PROPOSAL PI-PKPP, PTAPB-BATAN (2012)

3. DARSONO, SUYAMTO, dan E. NURAINI. "Disain Trafo Teganagan Tinggi Berfrekuensi Tinggi 40kHz/17,5kV Untuk STT Cockcroft Walton MBE Lateks" Prosiding Pertemuan dan Presentasi IImiah Teknologi Akaselarator dan Aplikasinya, (2012) 5-15

4. B. ABDI,. A. NASIRI, M.H. ASLINEZHAD, M. ABROSHAN, Energy Procedia, Volume 12 (2011) 656-661

5. F. J. GUTIERREZ ORTIZ, B. NAVARRETE, L. CANADAS, Fuel Processing Technology 91 (2010) 1783-1793

6. J. LIU, L. SHENG, J.SHI, Z. ZHANG, X. HE, "Design of High Voltage, High Power and High Frequency Transformer in LCC Resonant Converter", Applied Power Electronics Conference and Exposition, APEC 2009. Twenty-Fourth Annual IEEE, Washington DC (2009) 1034-1038

7. E. NURAINI, SUYAMTO, A.D. ATMOJO, "Karekterisai Gulungan dan Isolator Trafo Frekuensi Tinggi pada Sumber Tegangan Tinggi CW-MBE Lateks", Prosiding Pertemuan dan Presentasi IImiah Teknologi Akselerator dan Aplikasinya, Yogyakarta (2012) 74-81 
8. LOGBOOK MBE Lateks, Bidang Fisika Partikel, PSTA-BATAN (2014)

9. M. MARPAPUNG, Teori Soal dan Penyelesaian: Teknik Tenaga Listrik, Armico, Bandung (1979).

10. W.T. MCLYMAN, Transformer and Inductor Design Handbook, Marcel Dekker, New York and Basel (2004)

11. R. L. BOYLESTAD, Introductory Circuit Analysis, $12^{\text {th }}$ Edition, Prentice Hall International Inc, USA (2010)

12. M. CHOLIL, SUPRAPTO, SUYAMTO, "Disain Sistem Pendingin Transformator Frekuensi Tinggi Pada Mesin Berkas Elektron $300 \mathrm{keV} / 20 \mathrm{~mA}$ ", Prosiding Pertemuan dan Presentasi Ilmiah Teknologi Akaselarator dan Aplikasinya, Yogyakarta (2012) 89-94

13. http://www.scribd.com/doc/217586735/Perubahan-Efisiensi-Terhadap-Beban-Pada-Transformator-1-Fas a-Adri-Hamda-Academia, diakses Maret (2014) 